\title{
EFFECT OF TWO LEVELS OF PROBIOTICS SUPPLEMENTATION ON PERFORMANCE, DIGESTIBILITY, AND SOME BLOOD CONSTITUENTS IN WEANED LAMBS
}

\author{
A. M. Saleem ${ }^{1}$ and A.I. Zanouny ${ }^{2}$ \\ ${ }^{1}$ Animal and Poultry Production Department, Faculty of Agriculture, South Valley University, Qena \\ 83523, Egypt \\ ${ }^{2}$ Animal and Poultry Production Department, Faculty of Agriculture, Minia University, Minia, Egypt
}

(Received 1/5/2016, Accepted 16/6/2016)

\section{SUMMARY}

\begin{abstract}
$\mathrm{T}$ his study was conducted to investigate the effects of feeding weaned lambs on diets supplemented with two levels of commercial probiotic contains a mixture of two strains of Pediococcus, Pediococcus acidilactici (1 x $106 \mathrm{cfu} / \mathrm{g})$ and Pediococcus pentosaceus $(1.3 \times 106 \mathrm{cfu} / \mathrm{g})$, with dextrose as the carrier compound on growth performance, digestibility, and blood parameters. In a growth study, 24 weaned male Saidi lambs of about 3-4 months age and an average initial live BW of $15.88 \pm 0.57 \mathrm{~kg}$ were randomly allotted into three groups, one group received control diet without additives, and remainders received control diet supplemented with 0.5 or $1 \mathrm{~g}$ probiotic/lamb/day. The experimental period lasted for 84 days. Diets were offered twice a day for ad libitum intake and contained $80 \%$ concentrate and $20 \%$ roughage. Lamb BW and feed intake were recorded. Feed conversion ratio and economical efficiency were calculated. Blood samples were collected by month. In a digestibility study, fifteen lambs initial BW = $29.72 \pm 1.15 \mathrm{~kg}$, age $=6.54 \pm 0.32$ months) were used as experimental animals in a digestion trial. They were allocated randomly for three treatments (five per treatment) within live BW and age. Treatments contain $0,0.5$, and $1 \mathrm{~g}$ probiotic/lamb/day. Total DMI tended to be higher $(P=0.17)$ with increasing level of probiotics in the diets. Lambs fed $1 \mathrm{~g}$ /day of probiotic tended to have greater $(P \leq 0.10)$ daily gain, total gain, and a better feed conversion ratio and economical efficiency compared to the groups received control or $0.5 \mathrm{~g}$ probiotics/day. With the exception of either extract (EE) digestibility, all nutrients digestibility, total digestible nutrients (TDN), and digestible crude protein (DCP) values were increased with inclusion probiotic in the diets. Probiotics supplementation did not change serum constituents of total protein, albumin, globulin, and glucose levels, however blood urea and cholesterol concentrations were decreased $(P \leq 01)$ with increasing level of probiotic in the diet. In conclusion, supplementation of probiotic at high level of $1 \mathrm{~g} /$ day in weaned lamb diets may be have appositive effect on nutrients digestibility which result in improve growth performance, feed conversion, economic efficiency, and animal health through decrease cholesterol concentration in the blood.
\end{abstract}

Keywords: Probiotic, weaned lamb, growth, digestibility, blood metabolite

\section{INTRODUCTION}

The time around weaning is considered as the most stressful period in the life of lambs. The digestive system of early weaned lambs are not fully developed, which results in low feed intake, loss weight gain, immunity, and high diarrhoea cases and mortality. Most of the changes in microbial composition and population in the digestive tract can lead to health and performance problems in animals (Jonsson 1985). Sources of stress at weaning may be psychological, nutritional, environmental (Funderburke and Seerly, 1990). There are numerous naturally active substances, such as probiotics, supplements to the feed that are used to improve the animal production and potentially reduce the cost of animal breeding. Probiotics are characterized as dietary supplements containing most likely a live microorganism, which exhibit a beneficial effect on host animal performance and health by stimulating appetite (Nahashon et al., 1994), improving the balance of the intestinal microorganisms (Fuller, 1989), and digestion (Collins et al., 1999). Probiotics might be added to food or water as mono or mixed cultures of live microorganisms (Todorov et al., 2007). The utilization of probiotic as the feed additives has been developed as alternatives to antibiotics to enhance animal production and health (Allen et al., 2013). The valuable impacts of live microorganism products are associated with the improvement of microbial balance within the digestive 


\section{Saleem and Zanouny}

tract, feed efficiency and the release of indigenous products (Kalbande et al., 1992; Andersson et al., 2002; Bai and Ouyang 2006; Rioux and Fehdorak 2006).

The main commonly living microorganisms that can use as additives for ruminants are bacteria and yeasts, and it can be presented in different ways such as capsules, powder, paste, or granules. The most interesting probiotic preparations for animals and humans are those with specific species of live microorganisms such as Lactobacillus, ( $L$. acidophilus, L. bulgaricus, L. plantarum, L. casei), Streptococcus (S. faecium) and Bacillus (B. subtilis, B. licheniformis, B. cereus) which help enhancement the ruminal microorganism population (Lopez, 2000). Probiotics may produce their beneficial effects to the host animal by enhance nutrient synthesis and their bio-availability leading to higher growth performance (Oyetayo and Oyetayo, 2005), increase rumen cellulolytic bacteria population (Dawson, 1990), improve feed utilization and growth performance (Khalid et al., 2011), feed intake, average daily gain, feed conversion ratio, and nutrients absorption (Chiofalo et al., 2004; Antunovic et al., 2006; Whitley et al., 2009).

Probiotics are claimed to have many effects on the host. Among these effects are: improve DM intake, body weight gain and feed conversion ratio in ruminants (Abdel-Salam et al. 2014; Hussein, 2014; Ghazanfar et al., 2015). In a recent study El-Katcha et al. (2016) reported that growing lambs received Pediococcus spp. (bacteria probiotic) supplementation in drinking water result in higher final body weight and weight gain, better feed conversion efficiency, and improve nutrient digestibility and feeding values compare to control group, and this may be due to improve ruminal bacteria activity. This study hypothesized that probiotics have beneficial effects by improving nutrient synthesis, increase ruminal cellulolytic bacteria population, and this would be affect feed intake, lamb performance and health, diet digestibility, and metabolic parameters. Therefore, the objective of this study was to evaluate the effect of feeding two levels of probiotics on feed intake, growth performance, diet digestibility, and certain blood metabolites in weaned lambs as well as the economic efficiency of these diets.

\section{MATERIALS AND METHODS}

This study was conducted at the Animal and Poultry Production Department, Faculty of Agriculture, South Valley University Sheep Farm, Qena, Egypt, during the months of February through May, 2015.

\section{Growth study}

\section{Lambs and treatments}

This study has been conducted on 24 Saidi lambs after weaning using a completely randomized design. All lambs were treated for internal and external parasites and vaccinated for common infectious disease before the experiment started. The lambs were stratified into three separate groups $(n=8)$ on the basis of initial live body weight $(15.88 \pm 0.57 \mathrm{~kg})$ and age $(3 \pm 0.46$ months). Experimental groups were adapted to the control diets for two weeks before the start of the feeding trial then lambs were allocated randomly to one of the three experimental diets. The first group was fed control diet without probiotic, the second and third groups received the control diet plus 0.5 or $1 \mathrm{~g} /$ day, respectively. The experimental period lasted for 98 days, including a 14-day adaptation period and 84-day growth data collection period. The experimental diets were formulated to meet or exceed energy requirements according to NRC (2001) and fed to animals twice daily at 0800 and 01400 hour at equal amount with free access to water. The control diet consisted of concentrate and wheat straw and were weighed daily and fed separately to the animals. Lambs were fed concentrate mixture and wheat straw as ad libitum intake at a concentrate: roughage ratio of 80:20.

Probiotic was added separately in the experimental groups of the lambs in concentration of $0.5,1$ probiotics/lamb/day mixed with concentrate mixture throughout the study in the aim of equally mixing. According to the supplier, the commercial probiotic supplement used in this study contains a mixture of two strains of Pediococcus, P. acidilactici (1 x $106 \mathrm{cfu} / \mathrm{g}$ ) and $P$. pentosaceus $(1.3 \mathrm{x} 106 \mathrm{cfu} / \mathrm{g})$, with dextrose as the carrier compound. The product is intended for use with animals, birds and fish. The chemical compositions of concentrate mixture and rice straw used during trail are presented in Table 1. 
Egyptian J. Nutrition and Feeds (2016)

Table (1). Ingredients and chemical composition on DM basis (\%) of feedstuff and the experimental diet.

\begin{tabular}{lccccccc}
\hline Item & DM\% & OM & CP & CF & EE & NFE & Ash \\
\hline Concentrate mixture & 88.56 & 91.05 & 14.55 & 2.80 & 13.83 & 59.87 & 8.95 \\
Rice straw & 92.16 & 82.45 & 3.6 & 1.43 & 36.07 & 41.35 & 17.55 \\
Ration & 89.30 & 89.29 & 12.31 & 2.52 & 18.39 & 56.07 & 10.71 \\
\hline
\end{tabular}

Concentrate mixture contains: $40.0 \%$ yellow corn, $15.0 \%$ wheat bran, $15.0 \%$ cottonseed meal, $12.5 \%$ soybean meal, $15.0 \%$ molasses, $1.0 \%$ calcium carbonate, $1.0 \%$ sodium chloride and $0.5 \%$ mineral plus vitamins additives.

$D M=$ dry matter, $O M=$ organic matter, $C P=$ crude protein, $C F=$ crude fiber, $E E=$ ether extract, $N F E=$ nitrogen-free extract

\section{Measurements and sample collection}

All lambs were weighed every week in the morning after fasting (food and water) for 12 hours during the experimental period. A digital scale was used for monitoring of BW and feed conversion ratio. Initial and weekly BW was recorded on two successive days. Orts were recorded daily and DM intake by individual lambs was calculated daily from the difference between the amount of feed offered and the amount of feed refused. Furthermore, growth performance indices were calculated as follows: average daily gain (ADG, g/lamb/day) was calculated as the difference between the final and initial BW divided by the number of days on feed. Total weight gain, (TWG, $\mathrm{kg}$ ) was measured as the difference between final and initial weight. Growth rate $(\mathrm{GR}, \%)=$ (final weight-initial weight)/(initial weight) $x 100$. Feed conversion ratio (FCR) was calculated as the ratio between DM intake and ADG ( $\mathrm{kg}$ of DM intake/kg of BW gain).

\section{Samples collection and chemical analyses}

Representative samples of each ingredient (concentrate and roughage) were collected every 2 weeks and composited by month. The samples were ground in a Wiley mill to pass through a 1-mm sieve. Feed samples were subjected to proximate analysis following the standard methods of AOAC (1995). Representative samples were analyzed for dry matter (DM), organic matter (OM), crude protein (CP), crude fiber $(\mathrm{CF})$, either extract (EE), and ash (Tables 1). Dry matter content was determined by oven drying in a forced air oven at $105^{\circ} \mathrm{C}$ for 24 hours. The $\mathrm{OM}$ content was calculated as the difference between DM and ash contents. Crude protein content of feed was determined using Kjeldahl method, and ether extract was determined using the Soxhlet procedure. The nitrogen-free extract was calculated by differences. Ash content was determined by ashing the samples in a muffle furnace at $550^{\circ} \mathrm{C}$ for 5 hour.

\section{Blood samples and analyses}

Blood samples $(10 \mathrm{~mL})$ were taken from the jugular vein from each lamb before the morning feeding every month. One blood sample was collected into serum separator tubes, whereas a second blood sample was collected in tubes containing $5 \mathrm{mg}$ of sodium fluoride and $4 \mathrm{mg}$ of potassium oxalate for subsequent glucose determination. Following collection, samples were put immediately into ice and centrifuged on the same day at $2500 \mathrm{rpm}$ for 15 minutes at $4^{\circ} \mathrm{C}$ to separate serum and plasma then frozen at $-20^{\circ} \mathrm{C}$ until further analysis. Serum samples were subjected to analyze total protein, albumin, total lipid, urea, and cholesterol changes, while plasma was used for analysis of glucose using commercial kits. Total protein and albumin were determined according to Kaplan and Szalbo, 1983 and Doumas, (1971), respectively, and globulin concentration was calculated by the difference between the total protein and albumin concentrations. Total lipids and cholesterol were determined according to Schalm et al. (1975), and glucose was measured according to by method described by Trinder (1969).

\section{Digestibility study}

A digestion trial was conducted to assess the utilization of different dietary nutrients. By the end of the growth study, five lambs, (initial BW $=29.72 \pm 1.15 \mathrm{~kg}$, age $=6.54 \pm 0.32$ months) were randomly selected from each treatment group and assigned in individual digestibility cages. Dietary treatments (Table 1) included $0,0.5$, and $0.1 \mathrm{~g} / \mathrm{lamb} /$ day inclusion of probiotic in the diets. A digestion trial consisted of a $15 \mathrm{~d}$ for diet adaptation and a $7 \mathrm{~d}$ feces collection period. Lambs were fed concentrate and roughage separately as ad libitum intake at a concentrate: roughage ratio of 80:20. During the collection period, fecal samples were taken at $12 \mathrm{~h}$ intervals. The daily feces collected samples were weighed and mixed thoroughly by hand and subsamples representing $10 \%$ of daily fecal production from each lamb were frozen at $-5^{\circ} \mathrm{C}$ until being composited for the complete period collection. Representative samples of each daily collection of diets, orts and feces were pre-dried in drying oven at $60-70{ }^{\circ} \mathrm{C}$ for $48 \mathrm{~h}$ and 


\section{Saleem and Zanouny}

grounded through $1 \mathrm{~mm}$ mill screen openings and were saved for further analysis. Samples of diets, orts and feces were analyzed for DM, OM, CP, EE, CF and ash contents according to AOAC (1995) methods, while nitrogen-free extract (NFE) was calculated by differences.

\section{Income over the feed cost}

The economical efficiency was calculated as the ratio between income (income from gain) and cost of feed consumed. The costs of feeding probiotic were calculated. The cost of each individual ingredient in the experimental diets was calculated to estimate feed cost $/ \mathrm{kg}$ DM in Qena Governorate, Egypt as the following: $2500 \mathrm{LE} /$ ton of concentrate mixture; $500 \mathrm{LE} /$ ton of wheat straw; $500 \mathrm{LE} / \mathrm{kg}$ of probiotic; 36 $\mathrm{LE} / \mathrm{kg}$ of live BW at the time of the experiment.

Daily feed cost equalled the price of one kg feed multiplied by kilograms of feed consumed. Feed cost $/ \mathrm{kg}$ gain equalled the total feed cost divided by total body weight gain. Total interest equalled the (price of one $\mathrm{kg}$ live BW multiplied by total gain, $\mathrm{kg}$ ) minus (total feed cost). Interest $/ \mathrm{kg}$ gain equalled price of one kg live body weight gain minus feed cost divided by kg gain. Economic efficiency equalled price of daily body weight gain divided by daily feed cost.

\section{Statistical analysis}

The data were statistically analyzed using PROC MIXED procedure according of SAS (2004) for a completely randomized design. The statistical models used in this study were as follows:

$Y i j=\mu+T_{i}+E_{i j}$

where $Y i j$ is the observed response, $\mu$ is the overall mean, $T i$ is the effect of treatment (probiotic), and $\mathrm{E}_{\mathrm{ij}}$ is the experimental error. The differences $(P<0.05)$ among different groups were tested by the least significant differences (LSD) procedure of SAS which considered statistically significant.

\section{RESULTS AND DISSCUSION}

\section{Feed intake and performance}

Feed intake and performance of lambs fed the experimental diets are shown in Table 2. Total DM intake tended to be higher $(P=0.17)$ with increasing levels of probiotic in the lambs diet. As a result, intakes of digestible crude protein (DCP) and total nutrients digestibility (TDN) were greater $(P=0.0001)$ for probiotic groups than control group. A positive effect of supplementation of probiotics on feed intake may be due to increase cellulolytic bacteria population in the rumen (Dawson, 1990; Wallace and Newbold, 1993), or improve ruminal $\mathrm{pH}$, thus leading to enhance feed intake and fiber degradability (Umberger and Notter, 1989) of lambs fed probiotics diets. Addition of probiotics has been previously reported to improve feed intake (Chiofalo et al., 2004; Antunovic et al., 2006; 2005; Desnoyers et al., 2009). Mukhtar et al. (2010) reported that DM intake tended to be increased when lambs fed concentrate supplemented with probiotic compare to those fed concentrate only. In contrast, DM intake was not affected when lambs and goats kids were fed diets supplemented with probiotics (Titi et al., 2008; Hernandez et al., 2009).

The initial body weight (BW) was unaltered between lambs in all treatments groups. The final BW of the lambs received $1 \mathrm{~g}$ probiotic/day were significantly greater $(P=0.08)$ than the control group, but no differences $(P>0.05)$ when compared with lambs fed $0.50 \mathrm{~g}$ probiotic/day. The present results show that lambs received 0.5 and $1 \mathrm{~g}$ probiotic/day recorded numerically highest live BW, average daily gain $(\mathrm{ADG})$, total weight gain, and growth weight compare to control group, but the differences between treatments were not significant $(P>0.05)$. The highest growth indices values were observed for lambs received $1 \mathrm{~g}$ probiotics/day compare with other treatments. The improve final $\mathrm{BW}$, ADG, and total gain with increase level of probiotic in lamb diets in the present results may be due to increase DM intake and improved nutrients digestibility of dry matter (DM), organic matter (OM), crude protein (CP) and crude fiber (CF). In a recent study El-Katcha et al. (2016) reported that growing lambs received Pediococcus spp. (Bacteria probiotic) supplementation in drinking water result in higher final body weight and weight gain, and better feed conversion efficiency compare to control group, and this may be due to and improve ruminal bacteria activity and nutrients digestibility. Moreover, improvement in growth performance with probiotic supplementation may be due to a higher feed consumption, better feed efficiency (Antonovic et al., 2006). and or improve synthesis of microbial protein result in increase post-ruminal amino acids supply (Erasmus et al., 1992). Greater weight gain with diets containing probiotics could be due to improve DM intake, digestibility of crude fiber and crude protein, and reduce the incidence of diarrhoea 
Egyptian J. Nutrition and Feeds (2016)

Table (2). Intake and performance of weaned lamb fed diets containing different levels of probiotic

\begin{tabular}{|c|c|c|c|c|}
\hline \multirow[b]{2}{*}{ Item } & \multicolumn{3}{|c|}{ Treatment } & \multirow[b]{2}{*}{$P$-values } \\
\hline & Control & $0.5 \mathrm{~g}$ probiotic $/$ day & 1gr probiotic /day & \\
\hline No. of animals & 8 & 8 & 8 & --- \\
\hline Total DMI, g/lamb/d ${ }^{1}$ & $1115.00 \pm 4.28$ & $1123.33 \pm 5.58$ & $1126.67 \pm 2.11$ & 0.17 \\
\hline $\mathrm{DCPI}^{2}, \mathrm{~g} / \mathrm{h} /$ day & $86.64^{\mathrm{c}} \pm 1.59$ & $94.69^{\mathrm{b}} \pm 0.59$ & $103.75^{\mathrm{a}} \pm 0.51$ & $<.0001$ \\
\hline $\mathrm{TDNI}^{3}, \mathrm{~g} / \mathrm{h} / \mathrm{d}$ & $645.93^{c} \pm 9.43$ & $700.34^{\mathrm{b}} \pm 3.65$ & $724.29^{\mathrm{a}} \pm 6.57$ & $<.0001$ \\
\hline Initial weight, $\mathrm{kg}$ & $15.43 \pm 1.14$ & $15.72 \pm 0.94$ & $16.48 \pm 1.02$ & 0.76 \\
\hline $2^{\text {nd }}$ week, $\mathrm{kg}$ & $16.75 \pm 1.16$ & $16.62 \pm 0.98$ & $17.68 \pm 0.89$ & 0.73 \\
\hline 4th week, kg & $18.67 \pm 1.11$ & $18.42 \pm 1.02$ & $20.17 \pm 1.04$ & 0.47 \\
\hline $6^{\text {th }}$ week, $\mathrm{kg}$ & $21.08 \pm 0.99$ & $21.58 \pm 1.16$ & $22.83 \pm 0.98$ & 0.49 \\
\hline $8^{\text {th }}$ week, kg & $23.50 \pm 0.84$ & $24.25 \pm 1.24$ & $25.63 \pm 0.0 .82$ & 0.33 \\
\hline $10^{\text {th }}$ week, $\mathrm{kg}$ & $25.83 \pm 0.79$ & $26.58 \pm 1.33$ & $28.25 \pm 0.87$ & 0.27 \\
\hline Final weight, $\mathrm{kg}$ & $27.50^{\mathrm{b}} \pm 0.76$ & $28.75^{\mathrm{ab}} \pm 1.18$ & $30.66^{\mathrm{a}} \pm 0.79$ & 0.08 \\
\hline Growth rate, $\%$ & $81.65 \pm 10.21$ & $84.65 \pm 7.23$ & $88.73 \pm 9.09$ & 0.86 \\
\hline Daily gain, g/lamb/day & $143.65 \pm 8.34$ & $155.16 \pm 9.76$ & $168.85 \pm 5.42$ & 0.12 \\
\hline Total gain, $\mathrm{kg}$ & $12.07 \pm 0.70$ & $13.03 \pm 0.82$ & $14.18 \pm 0.46$ & 0.12 \\
\hline \multicolumn{5}{|l|}{ Feed conversion } \\
\hline $\mathrm{Kg} \mathrm{DMI} / \mathrm{kg}$ gain & $7.89 \pm 0.43$ & $7.40 \pm 0.52$ & $6.71 \pm 0.21$ & 0.16 \\
\hline $\mathrm{Kg}$ DCPI / kg gain & $0.61 \pm 0.04$ & $0.64 \pm 0.04$ & $0.62 \pm 0.02$ & 0.83 \\
\hline $\mathrm{Kg}$ TDNI /kg gain & $4.58 \pm 0.30$ & $4.75 \pm 0.36$ & $4.32 \pm 0.16$ & 0.55 \\
\hline
\end{tabular}

$\overline{a, b, c}$ values within a row with different superscripts differ significantly at $P<0.05$.

${ }^{1} D M I=$ dry matter intake.

${ }^{2} D C P I=$ digestible crud protein intake.

${ }^{3} T D N I=$ total digestible nutrients intake.

due to increase number of beneficial microorganisms in the rumen on calves (Lohnert et. al., 1999) or on Osmanabadi kids (Kochewad et al., 2009). In a study by Arab et al. (2014) used the same levels of probiotics in the present study reported that lambs received 0.5 and $1 \mathrm{~g}$ probiotic/kg feed have significantly $(P<0.05)$ higher body weight $(40.3$ and $39.0 \mathrm{~kg}$ respectively) compared to the control group $(38.1 .2 \mathrm{~kg})$.

The present results are agreement with Mallik et. al., (1998); Abas et al., (2007); Mukhtar et al., (2010); Hussein, (2014); Antunovicin et al., (2005) who reported that male lambs received probiotics had higher body weight gain than the control group. Haddad and Goussous (2005) reported that Awassi lambs fed diets supplemented with yeast culture recorded greater BW gain and better feed conversion ratio than the control group. Antunovic et al. (2006) reported that lambs fed probiotic treatment had a higher daily intake, body weight, daily gain, and improve feed conversion ratio compared to control group, with no significant differences among groups.

Feed conversion ratio expressed as $\mathrm{kg}$ DM intake/kg gain were numerically lower for lambs fed $1 \mathrm{~g}$ probiotic/day compare to those fed control or $0.5 \mathrm{~g}$ probiotic/day (6.71 vs. 7.89 and 7.40 , respectively), but no significant differences were found between treatments $(P>0.05)$. The improve feed conversion ratio (FCR) with probiotics supplementation in ruminants has been reported by other workers (Abe et al., 1995; Haddad and Goussous, 2005; Antunovic et al., 2006; Ding et al., 2008). Abe et al. (1995) reported that body gain and feed conversion ratio was improved when calves fed supplemented probiotic and this may be due to improve feed intake and crude fiber digestibility.

\section{Nutrients digestibility and feeding values}

Nutrients digestibility and nutritive values of the experimental diets are presented in Table 3. With the exception of either extract (EE) digestibility, the digestibility values of DM, OM, CP, CF, and NFE were improved $(P \leq 0.01)$ by lambs received high amount of probiotics $(1 \mathrm{~g} / \mathrm{lamb} /$ day $)$ compare to other treatments. Lambs received $0.50 \mathrm{~g}$ probiotics/day had significantly higher $(P<0.05) \mathrm{CP}, \mathrm{CF}$, and NFE digestibility than control group, were no differences in DM, OM, and EE digestibility were detected. There were significant differences $(P \leq 0.01)$ in DM, OM, and CP digestibility between the two probiotic groups. The nutritive values, expressed as total digestible nutrients (TDN) and digestible crude protein (DCP), showed that the lowest TDN and DCP values were shown by control (7.77 and 57.95\%, 
Saleem and Zanouny

Table (3). Averages of nutrients digestibility and nutritive value of experimental treatments

\begin{tabular}{|c|c|c|c|c|}
\hline \multirow[b]{2}{*}{ Item } & \multicolumn{3}{|c|}{ Treatment } & \multirow[b]{2}{*}{$P$-values } \\
\hline & Control & $0.5 \mathrm{~g}$ probiotic $/$ day & 1g probiotic /day & \\
\hline \multicolumn{5}{|c|}{ Apparent digestibility (\%) $)^{I}$} \\
\hline $\mathrm{DM}$ & $62.56 b \pm 1.96$ & $64.01 \mathrm{~b} \pm 1.52$ & $66.39 \mathrm{a} \pm 1.46$ & 0.005 \\
\hline $\mathrm{OM}$ & $64.41 b \pm 1.29$ & $65.28 \mathrm{~b} \pm 1.38$ & $67.29 \mathrm{a} \pm 1.51$ & 0.0005 \\
\hline $\mathrm{CP}$ & $63.18 c \pm 1.25$ & $68.52 b \pm 1.73$ & $74.88 \mathrm{a} \pm 1.33$ & $<.0001$ \\
\hline $\mathrm{CF}$ & $51.32 b \pm 2.30$ & $54.25 \mathrm{a} \pm 0.47$ & $55.26 a \pm 0.23$ & 0.03 \\
\hline $\mathrm{EE}$ & $65.18 \pm 1.85$ & $65.22 \pm 1.30$ & $66.33 \pm 1.10$ & 0.53 \\
\hline NFE & $66.07 \mathrm{~b} \pm 1.57$ & $71.73 \mathrm{a} \pm 0.93$ & $73.40 \mathrm{a} \pm 1.06$ & 0.002 \\
\hline \multicolumn{5}{|c|}{ Nutritive value ${ }^{2} \%$} \\
\hline DCP & $7.77 c \pm 0.15$ & $8.432 b \pm 0.09$ & $9.21 \mathrm{a} \pm 0.04$ & $<.0001$ \\
\hline TDN & $57.95 b \pm 1.03$ & $62.32 \mathrm{a} \pm 1.63$ & $64.28 \mathrm{a} \pm 1.61$ & 0.0002 \\
\hline
\end{tabular}

$\overline{a, b, c}$ Values within a row with different superscripts differ significantly at $P<0.05$.

${ }^{I} D M=$ dry matter, $O M=$ organic matter, $C P=$ crude protein, $C F=$ crude fiber, EE $=$ ether extract,$N F E=$ nitrogen-free extract.

${ }^{2} D C P=$ digestible crud protein, $T D N=$ total digestible nutrients.

respectively), while the highest values were recorded by groups received 0.5 and $1.00 \mathrm{~g}$ probiotic/day (8.432, 9.21\% and 62.32, 64.28\%, respectively), and significant difference $(P \leq 0.01)$ between treatments. Within probiotic groups, no significant difference was detected in TDN value.

The improved of nutrients digestibility with probiotic supplementation may be due to increased ruminal cellulolytic microbial population and improve rumenal $\mathrm{pH}$ (Ghazanfar et al., 2015). The present results are in agreement with others, Haddad and Goussous (2005) who showed that Awassi lambs fed diet supplemented with probiotic (yeast culture, YC) at levels 0,3 and $6 \mathrm{~g} / \mathrm{d}$ of YC, resulted in higher nutrients digestibility of DM, OM and apparent $\mathrm{CP}$ for $3 \mathrm{~g} / \mathrm{d}$ group compared to other groups. Mukhtar et al. (2010) reported that DM and CP digestibility were higher in lambs fed concentrate with probiotic than lambs fed concentrate only, but the difference was not significant. Moreover, Hillal et al. (2011) reported that supplementing the diet of growing lambs with probiotic improved the digestibility of DM, OM, CP, $\mathrm{CF}$, EE and NFE compare to control, but the differences in nutrients digestibility were not significant except for CP digestibility. On the other hand, Titi et al. (2008) reported that using probiotics (yeast culture) in Awassi lambs improved OM and acid detergent fiber (ADF) digestibility, with no effect on DM, CP and NDF digestibility. Supplementing the diet of weaned lambs (Ding et al., 2008), or goats (Whitley et al., 2009) with probiotic did not affect the digestibility of DM, OM, CP, NDF, and ADF compare to control group. Differences in the results of these studies may be due to the differences in the animal models used, environment, method of administration, level and type of addition of probiotic, or supplementation timelines (Whitley et al., 2009).

\section{Blood metabolites}

Total protein and their fractions, urea, cholesterol and glucose concentrations are presented in Table 4. No significant differences in total protein, albumin, globulin, and glucose concentrations were found between treatments. The values of these blood metabolites were within the normal range of healthy lambs fed diets containing probiotic. In the present study, supplementation of probiotic in the diet improvesd animal health status by didn't affect the level of blood sugar, and decreased cholesterol in blood serum. Moreover, the concentrations of blood urea of lambs fed the two levels of probiotic were significantly $(P$ $<0.05)$ lower when compared with lambs from the control group. Lambs received diets supplemented with $1 \mathrm{~g}$ probiotic/day had lower $(P=0.01)$ concentration of cholesterol compared to other treatments.

The lack effect of probiotic supplementation on blood total protein, albumin, globulin and glucose concentration are in agreements with Antunovic et al., (2006); Mohammed et al., (2013), El-Katcha et al., (2016) who reported that no significant differences in total protein, albumin, globulin and glucose levels on growing lambs and goats fed diets containing probiotic. Abdel Rahman et al. (2012) found that blood total protein and globulin concentrations were unaltered, and albumin concentration was significantly increased when yeast culture was inclusion in the sheep diet. Blood glucose concentration was not changed when lamb fed diets supplemented with probiotics (Ding et al., 2008). However, Hussein (2014) and Abdel-Salam et al., (2014) found that blood concentrations of total protein, albumin, globulin were greater when lambs received probiotics treatments compare to control diets. Whereas, Arab et al. (2014) reported that glucose, total protein, albumin, cholesterol, and triglyceride concentrations were decreased significantly $(P<0.05)$ in lambs received 0.5 or $1 \mathrm{~g}$ probiotic/kg feed compared to control group. 
The lower levels of urea in the blood of probiotic groups may be due to better utilization of nitrogen from food in the rumen. Similar results were seen by Antunovic et al. (2005, 2006); Ding et al. (2008); Bruno et al. (2009); Dimova et al. (2013), where the concentration of urea was statistically lower in the probiotic group compared to control group.

Table (4). Effects of increasing levels of probiotic in the diet on blood metabolite of weaned lambs

\begin{tabular}{lllll}
\hline Item & \multicolumn{4}{c}{ Treatment } \\
\cline { 2 - 4 } & Control & $0.5 \mathrm{~g}$ probiotic /day & $1 \mathrm{~g}$ probiotic $/$ day & $P$-values \\
\hline Total protein g/dL & $7.59 \pm 0.12$ & $7.47 \pm 0.18$ & $7.72 \pm 0.08$ & 0.43 \\
Albumin, g/dL & $3.68 \pm 0.18$ & $4.06 \pm 0.16$ & $3.92 \pm 0.20$ & 0.34 \\
Globulin, g/dL & $3.91 \pm 0.17$ & $3.42 \pm 0.27$ & $3.80 \pm 0.21$ & 0.27 \\
Glucose, mg/dL & $72.25 \pm 7.49$ & $72.87 \pm 5.59$ & $72.60 \pm 3.37$ & 1.00 \\
Urea, mg/dL & $35.17^{\mathrm{a}} \pm 0.22$ & $34.38^{\mathrm{b}} \pm 0.12$ & $33.99^{\mathrm{b}} \pm 0.28$ & 0.006 \\
Cholesterol, $\mathrm{mg} / \mathrm{dL}$ & $85.40^{\mathrm{a}} \pm 0.32$ & $84.88^{\mathrm{a}} \pm 0.22$ & $83.95^{\mathrm{b}} \pm 0.32$ & 0.01 \\
\hline$a, b, c$
\end{tabular}

${ }_{a, b, c}$ values within a row with different superscripts differ significantly at $P<0.05$.

\section{Income over the feed cost}

Economical efficiency and daily feed cost $/ \mathrm{kg}$ daily weight gain during the experimental period are shown in Table 5. The values of economical efficiency were highest in lambs receiving $1 \mathrm{~g}$ probiotic/day (2.57LE) followed by lambs receiving $0.5 \mathrm{~g}$ probiotic/day $(2.37 \mathrm{LE})$ and control (2.21LE). Improve economical efficiency with probiotic supplementation in the present study may be due to higher body weight gain for lambs fed probiotic compare to control group.

Table (5). Economical efficiency of lambs fed diets containing $0,0.5$ or $1 \mathrm{~g}$ probiotic.

\begin{tabular}{lccc}
\hline Item & \multicolumn{3}{c}{ Treatment } \\
\cline { 2 - 4 } & Control & $0.5 \mathrm{~g}$ probiotic /day & 1g probiotic /day \\
\hline No. of animals & 8 & 8 & 8 \\
Total DMI $^{1}, \mathrm{~g} / \mathrm{h} / \mathrm{d}$ & 1115 & 1123.33 & 1126.67 \\
Daily feed cost, LE & 2.36 & 2.37 \\
Daily body weight gain, kg & 2.34 & 155 & 169 \\
Price of daily BW gain, LE & 0.144 & 5.59 & 6.08 \\
Feed cost/kg gain, LE & 5.17 & 15.23 & 14.02 \\
daily interest, LE & 16.25 & 3.23 & 3.71 \\
Interest/kg gain, LE & 2.83 & 20.82 & 21.97 \\
Economic efficiency & 19.70 & 2.37 & 2.57
\end{tabular}

\section{CONCLUSION}

Supplementation of probiotic at level of $1 \mathrm{~g} / \mathrm{lamb} /$ day improved feed intake, Final BW, daily gain, decreasing feed conversion ratio, and economic efficiency compared to control group. Moreover, feeding of probiotic improved animal health status by didn't impact the level of blood sugar, and decrease cholesterol in blood serum.

\section{ACKNOWLEDGMENTS}

The authors would like to express their gratitude to the Sheep Farm staff of Animal and Poultry Production Department, faculty of Agriculture, South Valley University, Qena, Egypt for their assistance during the experiment period. 


\section{Saleem and Zanouny}

\section{REFERENCES}

Abas I, H.C. Kutay, R. Kahraman, N.Y. Toker, D. Ozcelik, F. Ates and A. Kacakci, 2007. Effects of organic acid and bacterial direct-fed microbial on fattening performance of Kivircik Male yearling lambs. Pak. J. Nutr. 6: 149-154.

Abdel Rahman, H., G.A. Baraghit, A.A. Abu El-Ella, S.S. Omar, F.F. Abo Ammo and O.F. Kommona, 2012. Physiological responses of sheep to diet supplementation with yeast culture. Egypt. J. Sheep \& Goat Sci. 7: 27-38.

Abdel-Salam A.M., M.M. Zeitoun and M.M. Abdelsalam, 2014. Effect of Synbiotic Supplementation on Growth Performance, Blood Metabolites, Insulin and Testosterone and Wool Traits of Growing Lambs. J. Bio. Sci. 14: 292-298.

Abe, F., N. Ishibashi and S. Shmimamure, 1995. Effect of administration of bifidobacteria and lactic acid bacteria to new born calves and piglets. J. Dairy Sci. 78:12

Allen, H.K., U.Y. Levine, T. Looft, M. Bandrick and T.A. Casey, 2013. Treatment, promotion, commotion: Antibiotic alternatives in food-producing animals. Trends Microbial. 21:114-119.

Andersson H., N.G. Asp, A. Bruce, S. Roos, T. Wadström and A.E. Wold, 2002. Health effects of prebiotics and probiotics: a literature review on human studies. Scandinavian Journal of Nutrition/Näringtorskning 45:58-75.

Antunovic Z., M. Speranda, B. Liker, V. Seric, D.Sencic, M. Doma-cinovic and T. Sperandat, 2005. Influence of feeding the probiotic Pioneer PDFM® to growing lambs on performances and blood composition. Acta Vet., 55: 287-300.

Antunovic Z., M. Speranda, D. Amidzic, V. Seric, Z. Steiner, N. Doma-Cinovic and F. Boli, 2006. Probiotic application in lambs nutrition. Krmiva, 4, 175-180.

AOAC., 1995. Official Methods of Analysis. $16^{\text {th }}$ edn. Association of Official Analytical Chemists, Arlington, VA, USA.

Arab, H.A., A.M. Esmaeil, M. Rezaeian and M. Mohtasebi, 2014. Effects of bacillus subtilis and bacillus licheniformis-based probiotic on performance, hematology parameters and different blood metabolites in lambs. Inter. J. Food and Nutr. Sci. 4, 8-15.

Bai, A.P. and Q. Ouyang, 2006. Probiotic and inflammatory bowel disease. Postgraduate Medical Journal 82:376-382.

Bruno, R.G.S., H.M. Rutigliano, R.L. Cerri, P.H. Robinson and J.E.P. Santos, 2009. Effect of feeding Saccharomyces Cerevisiae on performance of dairy cows during summer heat stress. Anim. Feed Sci. Tech., 150: 175-186.

Chiofalo, V., L. Liotta and B. Chiofalo, 2004. Effects of the administration of lactobacilli on body growth and on the metabolic profile in growing Maltese goat kids. Reprod. Nutr. Dev., 44: 449-457.

Collins, M. D., and G. R. Gibson. 1999. Probiotics, prebiotics, and synbiotics: approaches for modulating the microbial ecology of the gut. Am. J. Clin. Nutr. 69 (Suppl. 1):1052.

Dawson, K.A., K.E. Newman and J.A. Boling, 1990. Effect of supplement containing yeast and lactobacilli on roughage feed ruminal microbial activities. J. Anim. Sci. 68:3392-3398.

Desnoyers M, S. Giger-Reverdin, G. Bertin, C. Duvaux-Ponter and D.Sauvant, 2009. Meta-analysis of the influence of Saccharomyces cerevisiae supplementation on ruminal parameters and milk production of ruminants. J. Dairy Sci., 92:1620-1632.

Dimova, N., M.,Baltadjieva, V. Karabashev, S. Laleva, Y. Popova, P. Slavova, J. Krastanov and G. Kalaydjiev, 2013. Effect of adding of probiotic "ZOOVIT" at feeding of lambs from breed synthetic population Bulgarian milk. Bulgarian Journal of Agricultural Science Supplement 19: 98-101.

Ding, J., Z.M. Zhou, L.P. Ren and Q.X. Meng, 2008. Effect of Monensin and live yeast supplementation on growth performance, nutrient digestibility, carcass characteristics and ruminal fermentation parameters in lambs fed steam-flaked corn-based diets. Asian-Aust. J. Anim. Sci., 21: 547-554.

Doumas, B.T., W.A. Watson and H.G. Biggs, 1971. Albumin standards and measurement of serum albumin with bromcresol green. Clin. Chim. Acta 31: 87-96. 
El-Katcha, M.I., M. A. Soltan, M.S. Essi. 2016, Effect of Pediococcus spp. supplementation on growth performance, nutrient digestibility and some blood Serum biochemical changes of fattening lambs. Alex. J. Vet. Sci. 49 (1): 44-54.

Erasmus, L.J., P.M. Botha and A. Kistner, 1992. Effect of yeast culture supplement on production, rumen fermentation and duodenal nitrogen flow in dairy cows. J. Dairy Sci., 75: 3056-3065.

Fuller, R. 1989., A review: Probiotics in man and animals. J. Appl. Bacteriol. 66, 365-378.

Funderburke D.W., Seerley R.W. 1990. The effects of postweaning stressors on pig weight change, blood, liver and digestive tract characteristics. J Anim Sci. 68(1):155-62.

Ghazanfar S., M. I. Anjum, A. Azim and I. Ahmed, 2015. Effects of dietary supplementation of yeast (Saccharomyces cerevisiae) culture on growth performance, blood parameters, nutrient digestibility and fecal flora of dairy heifers. J. Anim. Plant Sci. 25(1): 53-59.

Haddad, S.G and S.N. Goussous, 2005. Effect of yeast culture supplementation on nutrient intake, digestibility and growth performance of Awassi lambs. J. Anim. Feed Sci. Tech., 118: 343- 348.

Hernandez, R., S.S. Gonzalez, J.M. Pinos-Rodrigues, M.A. Ortega, A. Hernandez, G. Bueno and M. Cobos, 2009. Effect of yeast culture on nitrogen balance and digestion in lambs fed early, and mature orchard grass. J. Appl. Anim. Res., 32: 53-56.

Hillal, H., G. El-Sayaad and M. Abdella, 2011. Effect of growth promoters (probiotics) supplementation on performance, rumen activity and some blood constituents in growing lambs. Arch Tierz 54 (2011) 6, 607-617

Hussein, A.F., 2014. Effect of biological additives on growth indices and physiological responses of weaned Najdi ram lambs. Journal of Experimental Biology and Agricultural Sciences, 2(6), 597-607.

Jonsson, E. (1985). Lactobacilli as probiotics to pigs and calves - a microbiological approach. Swedish University of Agricultural Sciences Department of Animal Nutrition and Management, Uppsala, Sweden, Report No 148.

Kalbande, V.H., M.A. Gaffar, and S.V. Deshmukh, 1992. Effect of probiotic and nitrofurin on performance of growing commercial pullets. Indian Journal of Poultry Sciences 27:116-117

Kaplan, A. and J. Szalbo, 1983. Clinical chemistry: interpretation and techniques. 2nd ed. p157.

Khalid, M. F., M. Shahzad, A, M. Sarwar, A. U. Rehman, M. Sharif, and N. Mukhtar, 2011. Probiotics and lamb performance: A review. Afr. J. Agric. Res. Vol. 6(23), pp. 5198-5203.

Kochewad, S.A., J.M. Chahande, A.B. Kanduri, D.S.Deshmukh, S.A. Ali and V.M. Patil, 2009. Effect of Probiotic supplementation on Growth parameters of Osmanabadi Kids. Veterinary World, 2(1): 2930.

Lohnert, H.J., W.L. Ochrimenko and J. Bargholz, 1999. Influence of the feed additive "Toyocerin" on the rearing result of calves. In: Symposium vitamins and additive in nutrition of man and animal, 7. , Jena. Abstracts. Jena, thuringia: Institut fur Emahrungswissenschaften- Universitat Jena. p. 52.

Lopez, J., 2000. Probiotics in animal nutrition. Asian Australian Journal of Animal Sciences, 13: 12-26.

Mallik, R. and D.D. Sharma, 1998. Influence of mixed probiotic on growth feed conversion efficiency and incidence of diarrhoea in young calves. Ind. J. of Ani. Nutr. 15:228-231.

Mohammed, H.H., B.M. El-Sayed and M.A. Ali, 2013. Effects of commercial feed additives on performance, economic efficiency, blood metabolites and some maintenance behaviour in goats. Journal of Veterinary Science \& Medical Diagnosis 2,2-7.

Mukhtar, N., M. Sarwar, M.U. Nisa, M.A. Sheikh, 2010. Growth response of growing lambs fed on concentrate with or without ionophores and probiotics. International Journal of Agricultural \& Biological 12: 734-738.

Nahashon, S. N., H. S. Nakaue, S. P. Snyder, and I. W. Mirodh. 1994. Performance of Single Comb White Leghorn layers fed corn-soybean meal and barley-corn soybean meal diets supplemented with a directed-fed microbials. Poultry Sci. 73: 1712-1723.

NRC, 2001. Nutrient Requirements of Small Ruminants: Sheep, Goats, 6th edition, Cervids, and New World Camelids. National Academy Press, Washington, DC, USA. 


\section{Saleem and Zanouny}

Oyetayo, V.O. and F.L. Oyetayo, 2005. Potential of probiotics as biotherapeutic agents targeting the innate immune system. Afr. J. Biotech., 4: 123-127.

Rioux, K.P. and R.N. Fedorak, 2006. Probiotics in the treatment of inflammatory bowel disease. J. of Clin. Gast. 40:260-263.

SAS 2004. SAS/STAT User's Guide: Version 9.1 edin. SAS Institute Inc., Cary, NC. USA

Schalm, O.W., N.C. Jain and E.J. Corroll, 1975. "Veterinary Hematology". 3rd Ed., Lea \& Febiger, Philadelphia, USA.

Titi, H.H., R.O Dmour, and A.Y. Abdullah, 2008. Growth performance and carcass characteristics of Awassi lambs and Shami goat kid culture in their finishing diet. J. Anim. Sci., 142: 375-383.

Todorov, N., I. Krachunov, A. Alexandrov and D. Djuvinov, 2007. Guide on Animal Nutrition. Matkom, Sofia.

Trinder, P. 1969., Determination of glucose in blood using glucose oxidase with an alternative oxygen receptor. Ann. Clin. Biochem,6, 24-27.

Umberger S.H. and D.R. Notter, 1989. Evaluation of lactobacillus inoculants on feedlot lamb performance. J. Anim. Sci., 8: 40-45.

Wallace R.J. and C.J. Newbold, 1993. Rumen fermentation and its manipulation: The development of yeast culture as feed additives. In: Biotechnology in the Feed Industry, Lyons, T.P. (ed.). Alltech Technical Publications, Kentucky, pp. 173-192.

Whitley, N.C., D. Cazac, B.J. Rude, D. Jackson-O’Brien and S, Parveen. 2009. Use of commercial Probiotics supplement in meat goat. J. Anim. Sci., 87:723-728. 
تأثير إضافة مستويين من البروبيوتكك علي أداء ، هضم المواد الغذائية وبعض مكونات الدم في الحملان المفطومة

\author{
عاطف محم سليم عبدالله 1 و عبدالرحمن إبراهيم زانوني²

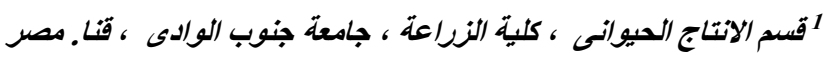

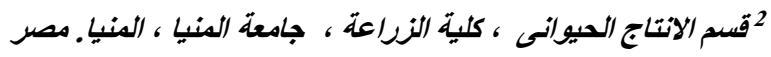

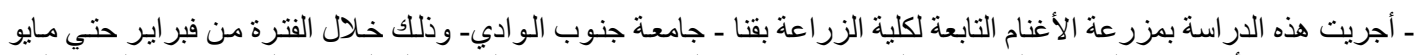

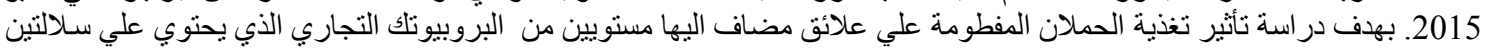
من Sediococcus acidilactici (1 x 106 cfu/g) , Pediococcus pentosaceus (1.3 x 106 cfu/g) مع الدكستروز

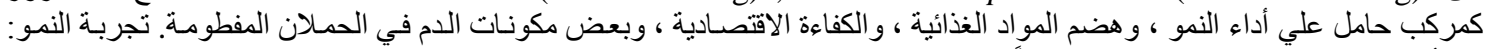

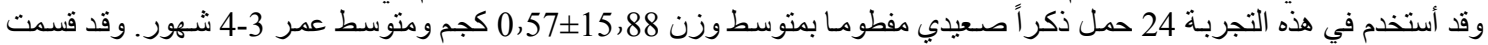

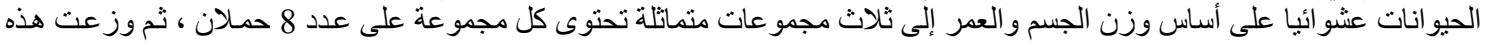

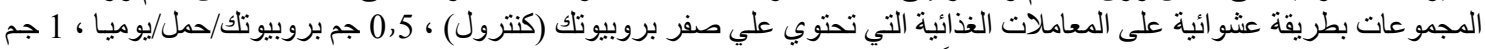

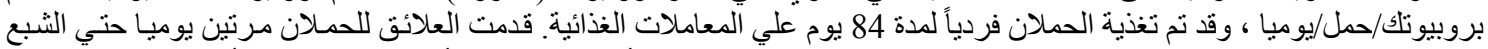

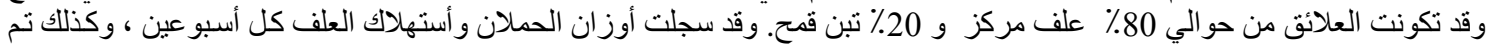

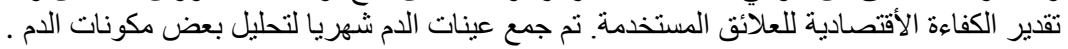

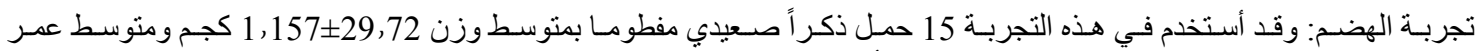

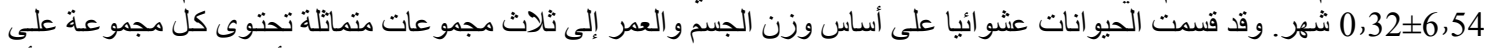

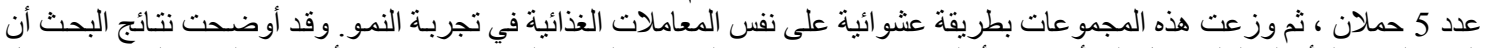

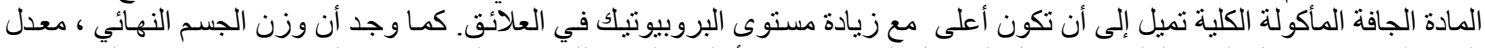

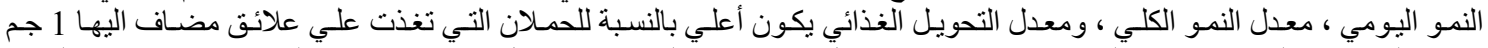

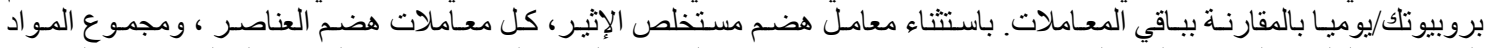

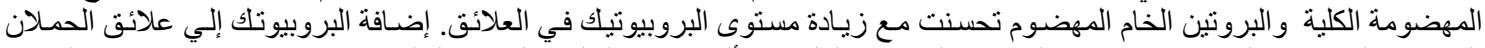

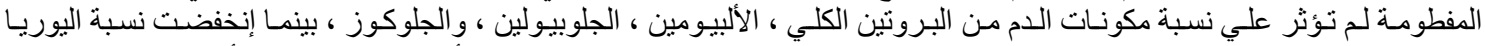

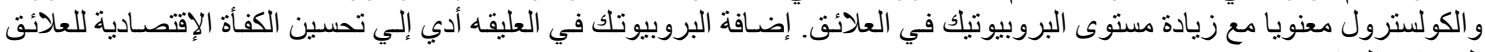
المضاف اليها.

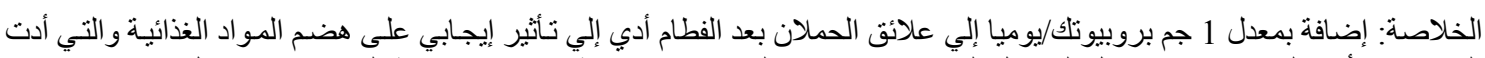

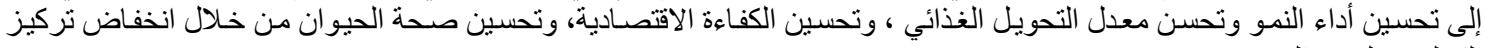
الكولسترول في الدم. 